\title{
Badania połączeń spawanych poddanych wahadłowemu zginaniu
}

\author{
Investigation welded joints \\ subjected to oscillatory bending
}

\section{Streszczenie}

W pracy zaprezentowano wyniki badań próbek z pachwinowym złączem spawanym, wykonanych ze stali S355, poddanych wahadłowemu zginaniu. Badania przeprowadzono przy stałej wartości amplitudy momentu i współczynnika asymetrii cyklu z częstotliwością obciążenia wynoszącą 28,4 Hz. Próbki posiadały koncentrator naprężeń w postaci zewnętrznego, dwustronnego karbu i pachwinowych złączy spawanych.
\end{abstract}

Słowa kluczowe: spawanie; zginanie; wzrost pęknięć zmęczeniowych; struktura

\section{Abstract}

The paper presents the results of tests on specimens of fillet welded joint, made of steel S355 subjected to oscillatory bending. Tests were performed at a constant amplitude of moment and stress ratio at a frequency of $28.4 \mathrm{~Hz}$ load. Specimens had a stress concentrator in the form of external bilateral notch and fillet welds.

Keywords: welding; bending; fatigue crack growth; structure

\section{Wstęp}

Projektowanie bezawaryjnych i bezpiecznych urządzeń technicznych w różnych gałęziach przemysłu ma ogromne znaczenie. Wiedza z zakresu wytrzymałości materiałów a tym bardziej trwałości zmęczeniowej, inicjacji i rozwoju pęknięć umożliwia tzw. bezpieczne podejście do konstruowania i budowy urządzeń technicznych. Najczęściej stosowanymi połączeniami nierozłącznymi w przemyśle są połączenia spawane. Niezależnie od rodzaju połączeń czy sposobu ich wykonywania w trakcie eksploatacji badacze prowadzący okresowe badania wykrywają pęknięcia zmęczeniowe.

Autorzy postawili sobie za cel opis rozwoju pęknięć zmęczeniowych w pachwinowych złączach spawanych ze spoinami wklęsłymi i wypukłymi wykonanych ze stali S355, poddanych wahadłowemu zginaniu.

\section{Przygotowanie próbek do badań}

Próbki do badań wykonano ze stali S355. Kształt oraz wymiary badanych próbek, litej oraz z wklęsłym złączem spawanym, pokazano na rysunku 1.

Próbki wykonane zostały z pręta ciągnionego o średnicy $\varnothing 30 \mathrm{~mm}$, z którego wykonano dwa rodzaje elementów składowych próbek (rys. 2), połączonych następnie dwustronnymi spoinami wklęsłymi lub wypukłymi. Złącza spawane wykonano ręcznie metodą TIG w osłonie argonu. Dodatkowo w czasie spawania podawano drut spawalniczy o oznaczeniu W-42-2-W2Sil zgodnie z PN-EN 1668 [1]. Teoretyczny współczynnik kształtu karbu wyznaczono dla próbki litej zgodnie z równaniem podanym w pracy [2], który dla obciążeń zginających wynosi $a_{k}=1,38$. Na rysunku 3 przedstawiono gotowe próbki do badań ze spoinami wklęsłymi i wypukłymi.

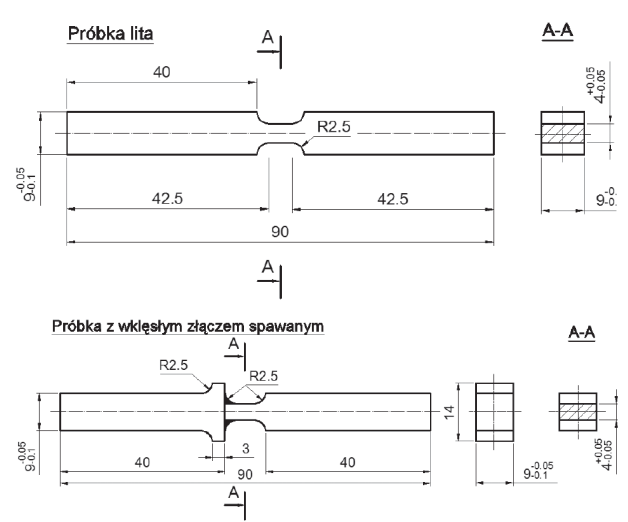

Rys. 1. Kształt i wymiary próbek: litej i z wklęsłą spoiną pachwinową Fig. 1. The shape and dimensions of the specimens: the solid and with fillet weld (concave connector welded)

Próbki wykonane zostały z pręta ciągnionego o średnicy $\emptyset 30$ mm, z którego wykonano dwa rodzaje elementów składowych próbek (rys. 2), połączonych następnie dwustronnymi spoinami wklęsłymi lub wypukłymi. Złącza spawane wykonano ręcznie metodą TIG w osłonie argonu. Dodatkowo w czasie spawania podawano drut spawalniczy o oznaczeniu

Mgr inż. Janusz Lewandowski; dr hab. inż. Dariusz Rozumek, prof. nzw. PO; dr Maria Hepner - Politechnika Opolska.

Autor korespondencyjny/Corresponding author. d.rozumek@po.opole.pl 
W-42-2-W2Sil zgodnie z PN-EN 1668 [1]. Teoretyczny współczynnik kształtu karbu wyznaczono dla próbki litej zgodnie z równaniem podanym w pracy [2], który dla obciążeń zginających wynosi $a_{k}=1,38$. Na rysunku 3 przedstawiono gotowe próbki do badań ze spoinami wklęsłymi i wypukłymi.

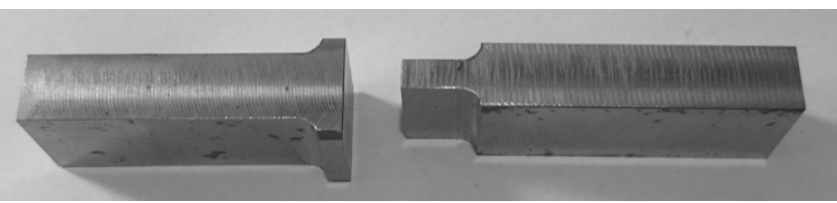

Rys. 2. Elementy składowe badanych próbek

Fig. 2. Components test specimens

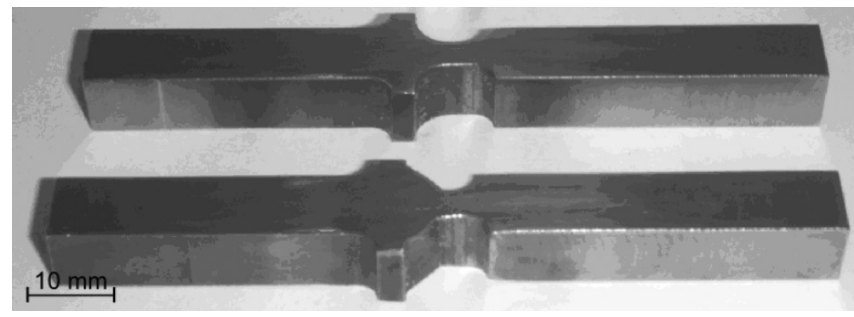

Rys. 3. Próbki do badań ze spoinami wklęsłymi i wypukłymi

Fig. 3. The test specimens: with a concave and convex welded joint

\section{Stanowisko do badań}

Badania przeprowadzano na maszynie zmęczeniowej MZGS-100 przy zginaniu i wartości współczynnika asymetrii cyklu $R=-1$ [3]. Jednostronnie utwierdzone próbki, poddano cyklicznemu zginaniu stałą amplitudą momentu $M_{a}=9,20 \mathrm{~N} \cdot \mathrm{m}$, co odpowiadało nominalnej amplitudzie naprężenia normalnego $\sigma_{a}=383 \mathrm{MPa}$ przed pojawieniem się pęknięcia. Rozwój pęknięć obserwowano metodą optyczną na powierzchni próbek. Przyrosty pęknięć zmęczeniowych mierzono za pomocą mikrometru cyfrowego umieszczonego w mikroskopie przenośnym o powiększeniu $25 \mathrm{x} z$ dokładnością 0,01 mm, notując jednocześnie liczbę cykli obciążenia N. Badania na zginanie prowadzone były z częstotliwości obciążenia $28,4 \mathrm{~Hz}$. Moment wywoływano siłą na ramieniu o długości 0,2 m.

\section{Wyniki badań $\mathrm{i}$ ich analiza}

\section{Pomiary twardości}

Na wybranych losowo próbkach przeprowadzono badanie twardości metodą Vickersa HV01, zgodnie z PN-EN 1043-1 [4]. Kryterium akceptacji była różnica pomiędzy twardością złącza, a materiału rodzimego, która nie może przekraczać 100 HV. Na rysunku 4 pokazano wykres zmienności wartości twardości w zależności od położenia punktu pomiarowego. Widać, że w materiale rodzimym twardości utrzymywały swoje wartości na podobnym poziomie. W strefie wpływu ciepła (SWC) widoczne są silne wahania wartości twardości. Następnie przechodząc do materiału spoiny zaobserwowano, że wartości te ulegają stabilizacji (nieznaczne wahania punktów pomiarowych).

\section{Obserwacje strukturalne}

Na rysunku 5 przedstawiono strukturę materiału badanej próbki litej ze stali S355. Materiał charakteryzuje się drobnoziarnistą strukturą ferrytyczno-perlityczną wykazującą drobne równoosiowe ziarna ferrytu oraz bardzo drobny perlit w układzie pasmowym. Perlit odznacza się bardzo drobną strukturą płytkową z częściową koagulacją cementytu.

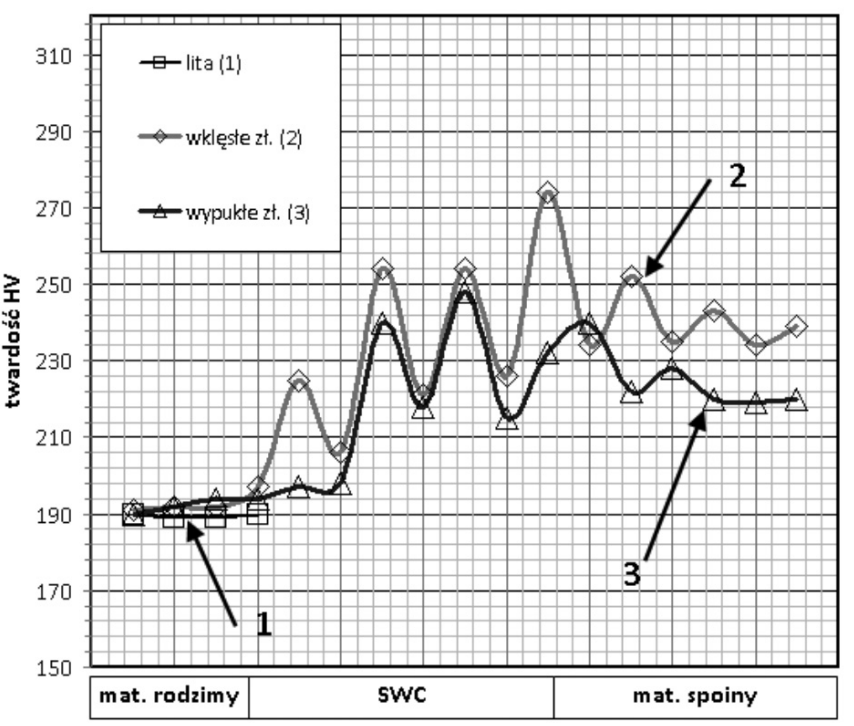

Rys. 4. Pomiary twardości z podziałem na strefy

Fig. 4. Hardness measurements with divided into zones

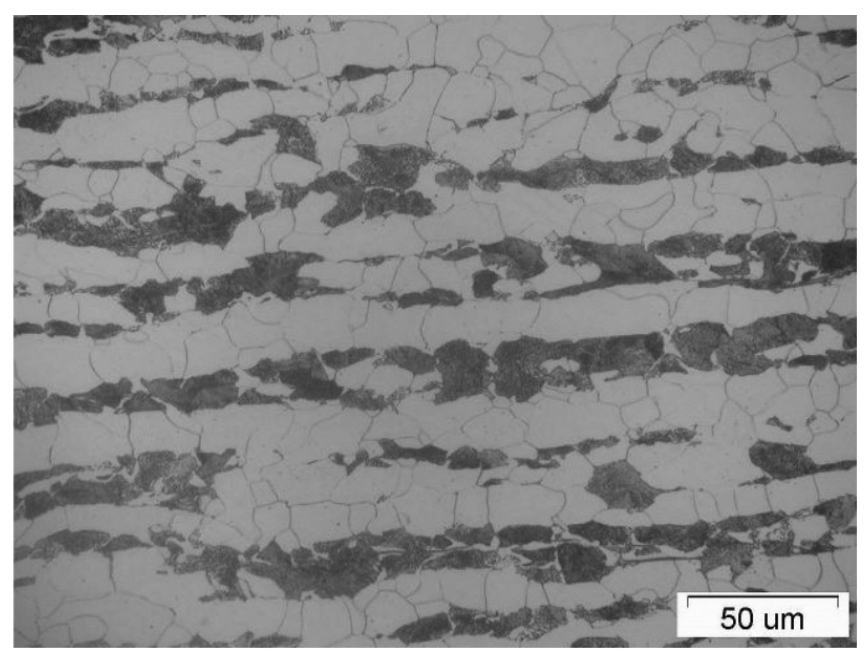

Rys. 5. Struktura materiału rodzimego (powiększenie 500x)

Fig. 5. The structure of the base material (magnification 500x)

Na rysunku 6 przedstawiono strukturę materiału próbki ze spoiną zarówno wklęsłą jak i wypukłą. W spoinach obydwóch rodzajów próbek zaobserwowano budowę dendrytyczną z ziarnami w układzie Widmanstattena (rys. 6a). W SWC występuje gruboiglasta struktura martenzytu i bainitu górnego w układzie Widmanstattena, struktura bainitu dolnego, drobnoziarnista strefa normalizowana (powstała przy nagrzaniu materiału rodzimego powyżej A3), strefa częściowo przekrystalizowana, charakteryzująca się niejednorodną wielkością ziarna o stosunkowo dużych ziarnach ferrytu i znacznie rozdrobnionych ziarnach perlitu (rys. 6b-6e).

\section{Badanie pęknięć zmęczeniowych}

Na rysunku 7a przedstawiono przykładową fotografię inicjacji rozwoju pęknięcia zmęczeniowego próbki litej. Główne pęknięcie ma charakter nieregularny i przebiega zarówno po granicach ziaren jak i transkrystalicznie poprzez ziarna. Zmiana kierunku pęknięcia najczęściej zachodzi w pasmowych wydzieleniach perlitu. Obserwuje się również nieliczne, krótkie pęknięcia boczne inicjowane w pasmach perlitu (rys. 7b).

Na rysunku 8a przedstawiono fotografię inicjacji rozwoju pęknięcia zmęczeniowego próbki ze spoiną wklęsłą. Pęknięcie inicjowane było w dnie karbu w obszarze gruboiglastej struktury martenzytycznej i na całej swojej długości charak- 
a)

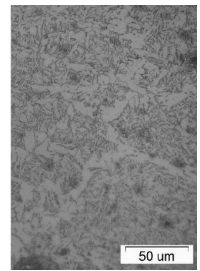

b)

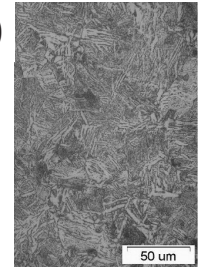

c)

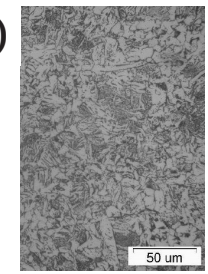

d)

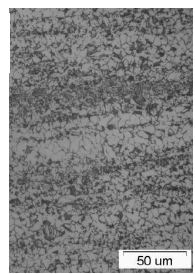

e)

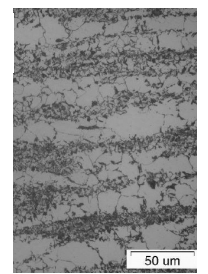

Rys. 6. Struktura złącza spawanego (powiększenie 500x): a) budowa dendrytyczna z ziarnami w układzie Widmanstattena, b) struktura martenzytu i bainitu górnego w układzie Widmanstattena, c) struktura bainitu dolnego, d) strefa normalizowana, e) strefa częściowo przekrystalizowana

Fig. 6. The structure of the parent material (solid specimens) (magnification 500x): a) the dendritic structure with grains in system Widmanstattena, b) the structure of martensite and upper bainite in system Widmanstattena, c) the structure of lower bainite, d) normalized zone, e) zone partially recrystallized
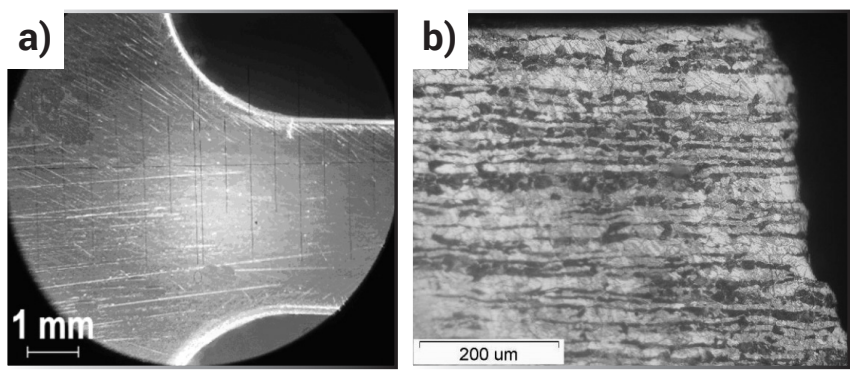

Rys. 7. Pęknięcie zmęczeniowe próbki litej przy cyklicznym zginaniu: a) inicjacja, b) struktura (powiększenie 200x)

Fig. 7. Fatigue cracks in the solid specimen in cyclic bending a) initiation, b) structure (magnification 200x)

teryzowało się nieregularnym przebiegiem, tworząc liczne „uskoki”, często wzdłuż igieł martenzytu (rys. 8b). Pęknięcie zasadniczo rozwija się $w$ kierunku prostopadłym do kierunku największych naprężeń normalnych. Przebiega ono w zróżnicowanej strukturze: martenzytycznej, bainitycznej oraz w strefie normalizacji. W tej ostatniej propagacja pęknięcia miała charakter bardzo regularny. Od pęknięcia głównego obserwuje się w obszarze struktury martenzytycznej i bainitycznej odchodzące rozgałęziające się pęknięcia boczne.

$\mathrm{Na}$ rysunku 9a przedstawiono fotografię inicjacji rozwoju pęknięcia zmęczeniowego próbki ze spoiną wypukłą. Pęknięcie główne inicjowane było $w$ dnie karbu na linii wtopienia i przebiegało prostopadle do kierunku największych
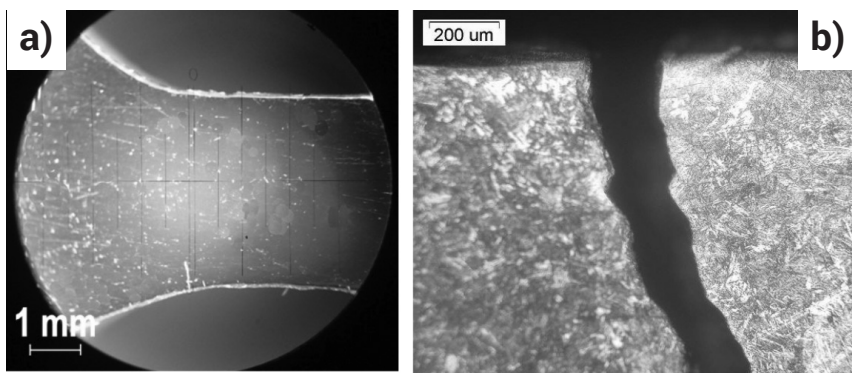

Rys. 8. Pęknięcie zmęczeniowe próbki litej przy cyklicznym zginaniu: a) inicjacja, b) struktura (powiększenie 200x)

Fig. 8. Fatigue cracks in the solid specimen in cyclic bending a) initiation, b) structure (magnification 200x)

naprężeń normalnych (rys. 9b). Od pęknięcia głównego odchodzą liczne krótkie pęknięcia boczne. Następnie pęknięcie główne przebiegało w strefie struktury normalizowanej i na tym etapie nie obserwowało się pęknięć bocznych.
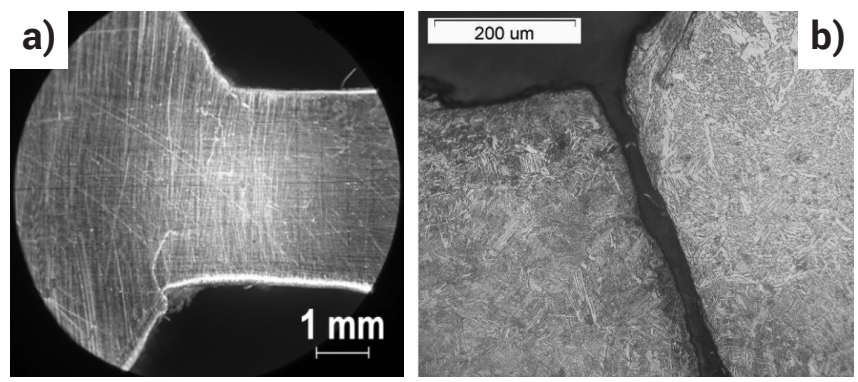

Rys. 9. Pęknięcie zmęczeniowe próbki ze spoiną wypukłą przy cyklicznym zginaniu: a) inicjacja, b) struktura (powiększenie 200x) Fig. 9. Fatigue cracks in the specimen with a convex connector weIded in cyclic bending a) initiation, b) structure (magnification 200x)

Podczas badań zaobserwowano, że inicjacja i rozwój pęknięć występowały z jednej strony próbki (z góry lub z dołu), a po pewnym okresie propagacji rozwój pęknięć występował również z drugiej strony (rys. 7-9). Na rysunku 10 przedstawiono przykładowe krzywe długości pęknięć zmęczeniowych w funkcji liczby cykli dla otrzymanych wyników badań. Na podstawie rys. 10 można zauważyć, że najmniejsze trwałości zmęczeniowe miały próbki ze spoiną wypukłą. Inicjacja pęknięć $(0,10 \mathrm{~mm})$ następowała przy 67000 cykli. Dalszy rozwój pęknięcia następował dość szybko i przy liczbie 74000 cykli próbka uległa zniszczeniu. W próbce ze spoiną wklęsłą po 44500 cykli zaobserwowano pęknięcie o długości 0,15 $\mathrm{mm}$. Rozwój pęknięcia następował z mniejszą prędkością, w porównaniu do rozwoju pęknięcia próbki ze spoiną wypukłą. Przy liczbie cykli 77500 próbka została zniszczona.

Próbka lita wykazała największą trwałość zmęczeniową w porównaniu do próbek spawanych. Inicjacja pęknięcia $(0,10$ $\mathrm{mm}$ ) wystąpiła po 85000 cykli i była wyższa niż w próbkach spawanych. Rozwój pęknięcia następował w szybszym tempie niż próbki ze spoiną wklęsłą ale w porównywalnym tempie do próbki ze spoiną wypukłą, a przy liczbie 98000 cykli próbka została zniszczona. Różnica w trwałości pomiędzy próbką z materiału litego, a próbką ze spoiną wklęsłą była większa o 31000 cykli (46\%). Różnica w trwałości pomiędzy próbką z materiału litego, a próbką ze spoiną wypukłą była większa o 24000 cykli (32\%). Widać więc, że przy tych samych badanych przekrojach i zastosowanym obciążeniu różnice są wyraźne.

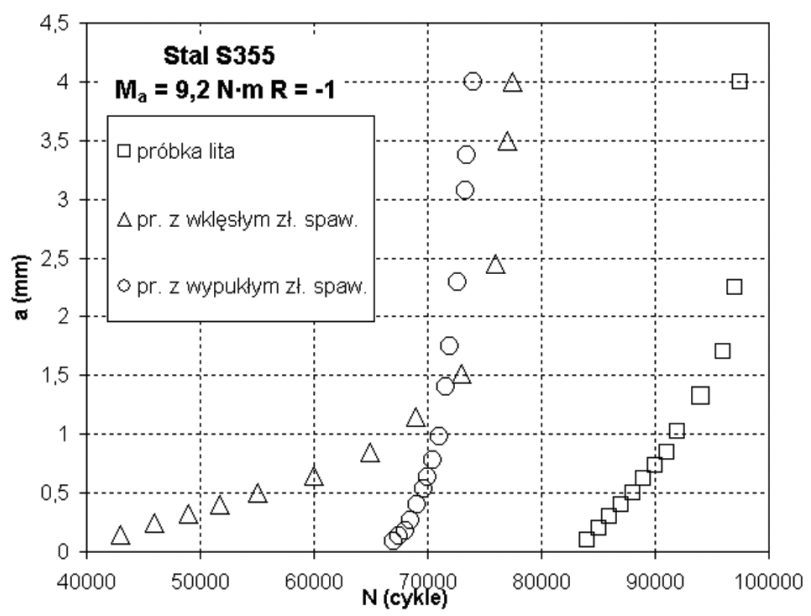

Rys. 10. Długości pęknięć zmęczeniowych w funkcji liczby cykli dla próbek poddanych zginaniu

Fig. 10. Fatigue crack length versus number of cycles for the specimens subjected to bending 


\section{Podsumowanie}

Na podstawie przeprowadzonych badań połączeń spawanych poddanych wahadłowemu zginaniu sformułowano następujące wnioski:

- Inicjacja pęknięć zmęczeniowych we wszystkich badanych próbkach rozpoczynała się w miejscu największej koncentracji naprężeń.

- Największą trwałość wykazały próbki wykonane z litego materiału. Ich trwałość w porównaniu do próbek ze spoinami wklęsłymi była wyższa o 32\%, a w porównaniu do próbek ze spoinami wypukłymi była wyższa o $42 \%$.

- Najmniejsze prędkości wzrostu pęknięć zmęczeniowych wykazały próbki ze spoinami wklęsłym.

- Próbki z litego materiału oraz próbki ze spoinami wypukłymi wykazywały podobne prędkości wzrostu pęknięć zmęczeniowych ale trwałości ich były różne.

\section{Literatura}

[1] PN-EN 1668:2000 Materiały dodatkowe do spawania -- Pręty, druty do spawania łukowego w osłonach gazów elektroda wolframową stali niestopowych i drobnoziarnistych oraz ich stopiwa - Klasyfikacja.

[4] PN-EN 1043-1:2000 Spawalnictwo -- Badania niszczące metalowych złączy spawanych -- Próba twardości -- Próba twardości złączy spawanych łukowo.

[2] Kocańda S., Szala J., Podstawy obliczeń zmęczeniowych, PWN, Warszawa 1985, s. 276.

[3] Rozumek D., Macha E., Opis rozwoju pęknięć zmęczeniowych w materiałach sprężysto-plastycznych przy proporcjonalnym zginaniu ze skręcaniem, Politechnika Opolska, Opole 2006, s. 196. 